of work in ports during 'alerts' unless danger is imminent. While the appointment of regional port directors by the Minister of Transport has been welcomed, the Sub-Committee points out that time alone will show whether such appointments, in some cases of men without previous experience of all the ramification of shipping and port management, is likely to bring success in discharging adequately and efficiently the very onerous responsibilities involved in securing the rapid clearance of both ports and ships.

Other recommendations in the tenth report include the acceleration of manufacture of railway wagons of special type ; closer co-operation at overseas ports between the Ministries of Shipping and Transport so that cargoes may be more suitably arranged with a view to their ultimate destinations; transfer of suitable engineers from industry to the merchant service and employment of an experienced shipbuilding engineer to visit repairing yards and suggest improvements in mechanical equipment. More ship repairs should, where possible, be effected abroad and among all practicable steps to overcome transport difficulties, the Sub-Committee reiterates its recommendation in the eighth report that particular attention should be directed to the possibility of curtailing or withdrawing passenger trains on specified days to permit more freight trains to be moved.

While the Sub-Committee considers that it is impracticable in war-time to contemplate a scheme submitted to them for concentrating railway traffic at stations 20 or 30 miles apart for exchange with road vehicles, and closing intermediate stations, such a scheme might repay further consideration after the War. In the meantime the Sub-Committee is awaiting the results of an investigation of the possibility of greater use being made of the canal system and also of proposals for using road transport in greater volume to assist the railways in clearing docks and other centres. It severely criticizes the failure of Government departments to consult the Mines Department when extensions or new factories are planned, and recommends that such Departments should be required to provide the Mines Department with quarterly estimates in advance in areas where supplies are short and future needs will expand. It also recommends that a more comprehensive scheme be planned at once to create coel stocks to meet next winter's demands, and that closer co-operation should be organized between coal merchants to pool requirements of stocks of household coal, labour and local transport.

\section{British Standards Institution}

Some months before the outbreak of war, the British Standards Institution offered the Government its services, as a complete unit, in the national emergency. This offer, which was sent to the Board of Trade, through which the Institution receives its Government grant, was cordially received. On the outbreak of war, the Institution set up a number of small executive committees for the various sections of its work, these being made fully responsible for the preparation of any war emergency specifications required. A statement has now been issued outlining the Institution's recent activities. The Institution has been invited to send a representative to appropriate meetings of the Materials Committee of the Production Executive, which is representative of all Government departments, the Central Priority Department acting as the liaison between that Committee and the Institution. The first issue of the War Emergency Specifications for Tins and Cans for food products and other commodities is estimated to have saved 40,000 tons of steel in the first year, while it is estimated that the War Emergency Specification for Bolts and Nuts with smaller heads will save many thousands of tons of steel a year.

Another example of the work of the Institution concerns alloy and special steels. A committee under the chairmanship of Dr. W. H. Hatfield, has for some time past been engaged on an investigation of this complex problem and has drawn up a confidential report which includes suggestions for a co-ordinated series of steels. Such sections of the report as can be made available to the engineering public are being issued by the Institution, which at the same time is issuing War Emergency British Standards covering the steels recommended in the report. The Ministry of Works and Buildings is using the Institution for the promulgation, under its authority, of a series of War Emergency British Standards, and about fifty specifications in connexion with A.R.P. work have been issued at the request of the Ministry of Home Security.

Such work of immediate importance has not prevented the British Standards Institution from maintaining its close relationship with the Dominions' standardizing bodies. In addition, the Institution's Committee in the Argentine Republic, which is working in close collaboration with the Argentine national standards organization, is receiving increased recognition, as its work is seen to be of real value to British export trade. British engineers and traders in the Argentine are to a greater degree giving practical support to the work of the Committee. The Institution, with the help of the British Council and of industry, is also engaged in compiling a number of technical handbooks dealing with British industrial practice. The books are to be published in Spanish and Turkish.

\section{Gypsy-Lore}

Ever since the time of Borrow the mystery of the gypsy-folk has intrigued those of us who have seen, and still occasionally see, their caravans encamped in some lovely dell; and Borrow would have been the first to welcome the serious study which since his day has been devoted to these people so that now we know much more about them than he could. The mystery, however, still remains. The current number of the Journal of the Gypsy-Lore Society makes interesting reading, its subject-matter ranging from the sixteenth century in Transylvania to modern 